\title{
Assessment of Well Water Quality for Drinking Purposes Within Selevania District, Zakho City, Kurdistan Region / Iraq
}

Musher R. A. Al- Barwary ${ }^{a}$

Dept. of Environmental Science, Faculty of Science, University of Zakho, Kurdistan Region, Iraq (musheer.ahmed@uoz.edu.krd)

Received: May., 2021 / Accepted: Sept., 2021 / Published: Sept., 2021

https://doi.org/10.25271/sjuoz.2021.9.3.813

\begin{abstract}
:
The world's major sources of drinking water are groundwater particularly wells water. In the present study, the quality of the wells in the 10 villages nearby the city of Zakho were selected for investigation and their suitability for drinking purposes. All the well water samples were analyzed for 11 chemical and physical analysis including dissolved oxygen, total hardness, chloride, total dissolved solids, electrical conductivity, $\mathrm{pH}$, sulfate, and four heavy metals, such as $\mathrm{Cu}, \mathrm{Fe}, \mathrm{Pb}$, and $\mathrm{Zn}$ using standard methods. The results showed that the value of heavy metals in well water samples were in these ranges: $\mathrm{Zn}(0.027 \pm 0.004$ to $0.005 \pm 0.007) \mathrm{mg} / \mathrm{L}$; $\mathrm{Fe}(0.0109 \pm 0.035$ to $0.183 \pm 0.061) \mathrm{mg} / \mathrm{L} ; \mathrm{Cu}(0.001 \pm 0.022$ to $0.025 \pm 0.023) \mathrm{mg} / \mathrm{L} ; \mathrm{Pb}(0.045 \pm 0.015$ to $0.069 \pm 0.096) \mathrm{mg} / \mathrm{L}$. The range of physical and chemical parameters were; $\mathrm{pH}$ (7.1 to 8.3), EC (411 to1579 $\mu \mathrm{S} / \mathrm{cm}$ ), TDS (263 to $1010 \mathrm{mg} / \mathrm{L}$ ), Total Alkalinity (287 to $584 \mathrm{mg} / \mathrm{L}$ ), Total hardness (176 to $848 \mathrm{mg} / \mathrm{L}$ ), Chloride (11.6 to $56.9 \mathrm{mg} / \mathrm{L}$ ), calcium ( 80 to $673 \mathrm{mg} / \mathrm{L}$ ), dissolved oxygen $(6.1$ to $8.7 \mathrm{mg} / \mathrm{L})$, sulfate $(10.3$ to $42.5 \mathrm{mg} / \mathrm{L})$ and temperature $\left(17.0\right.$ to $\left.23.4^{\circ} \mathrm{C}\right)$. The results were compared with international standards and showed that the mean values of total hardness and TDS in locations betas, Bezehe and Dolla are ranged from $(827.13$ $\pm 5.330),(544.25 \pm 3.178),(782.63 \pm 3.257),(930.38 \pm 3.545),(675.75 \pm 3.639),(996.25 \pm 3.245) \mathrm{mg} / \mathrm{L}$ respectively, were found to be higher than WHO water standards, and unsuitable for drinking use. The results have proven the presence of heavy metal as especially lead, $\mathrm{Zn}, \mathrm{Cu}$, and $\mathrm{Fe}$ have been containing in the study area. Other parameters were within (WHO) drinking water standards. In conclusion, the other sites of well water sources of the Selevania region are suitable for drinking purposes.
\end{abstract}

KEYWORDS: Heavy metals, well water, drinking water quality, Zakho city

\section{INTRODUCTION}

Water especially for drinking and domestic purposes is expected to be of suitable quality and without contaminants. As well water moves through differents geological layers in the sub-surface, it dissolves impurities of both inorganic and organic origin (Tajinder et al, 2016) Domestic water was exposed to dissolved metals, derived from natural and anthropogenic originates. The main sources of the poisonous metals in well water can be released from agricultural soil and chemical weathering of heavy metals, as well as anthropogenic action (Jabal et al ,2015).The anthropogenic sources involved the industrial effluent, domestic effluent, agriculture, landfill leachate, and mining activities.(Baskoro et al., 2019).Trace metals are natural components of the layers of earth, and cannot be destroyed. Some trace elements likes (e.g. $\mathrm{Zn}$ and $\mathrm{Cu}$ ) are important for the physiological process and have a toxic effect (Adam et al ., 2019). Groundwater is type of fresh water that used to supply for urban and rural area, $90 \%$ of freshwater source in the earth are coming from groundwater. Groundwater can be found in two type of storage that called hardrock aquifers and alluvial aquifer. (Mohamed et al., 2017). Water is responsible for about $86 \%$ of the major diseases in human. The chemical installation of well water is a measure of its suitability for animal and human consumption, Groundwater contain the dissolved ions which can affect the water's uses depending on their concentration and types of cations and anions found in wellwater contained Chromium, Manganese, Cadmium, Calcium, Cobalt, Sulfate, Copper, Zinc, Chloride Bicarbonate and Nitrate. Non-ionic such as oxides, synthetic detergents phenols, dissolved $\mathrm{CO}_{2}$ and $\mathrm{O}_{2}$ are also found in well water ( Yousra et al ., 2019). These criteria determine the quality of well water in terms of anions and cations. If it is present in above allowed limits of value, it may cause health hazards because of contamination and, the well water may need to be treated before utilization (Mohamed et al., 2017). The objectives of this study is to evaluated the chemical and physical characteristics of well water seasonly in the Zakho district and made comparison with WHO,standards of potable quality to ensure the quality of well water

\section{MATERIALS AND METHODS}

2.1 Study area: The research wells are located in selevania are near the Zakho district northern Iraq. The study area falls within Latitude: $37^{\circ} 08^{\prime} 55.36^{\prime \prime} \mathrm{N}$ and Longitude: $42^{\circ} 41^{\prime} 9.28^{\prime \prime}$ $\mathrm{E}$ and lies about $55 \mathrm{~km}$ north of Duhok city. The climate of the study area is hot, dry in summer and cold wet in winter 2.3 Statistical analysis. Data for chemical and physical parameters of well water samples were presented as mean values, standard deviation. Data collected were analysed for simple descriptive and inferential statistics using variance (ANOVA) was the statistical tool used together with computer SPSS 16.0 windows application.

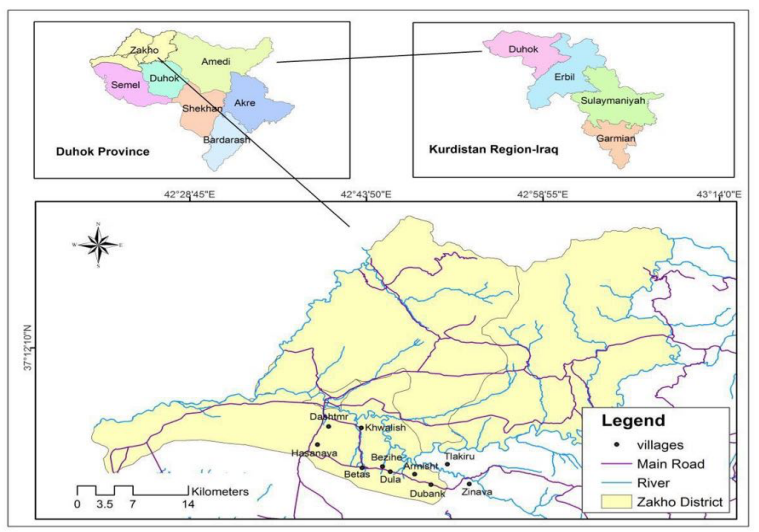

Figure 1: Map of Zakho district showing sampling locations, inflowing selevania well water 
2.2 Samples collection and analysis. 80 well water samples were collected from different sites of the study area. The depth of wells in the study area are between 77 to 85 meters. The well water samples were collected in 1-liter polythene bottles. The well water samples were collected from 10 different sites around Selevania subdistrict during the summer and winter seasons from August 2019 to March 2020. Well water samples were immediately transferred to the laboratory for chemical physical and physical analysis. The water samples were kept in a refrigerator at a temperature below $4{ }^{\circ} \mathrm{C}$, and analyzed within 3 day. The various water quality parameters like $(\mathrm{TH}, \mathrm{pH}$, TDS, $\mathrm{Mg}^{2+}, \mathrm{Ca}^{2+}, \mathrm{Cl}-, \mathrm{SO}^{-}{ }_{4}, \mathrm{EC}, \mathrm{TA}, \mathrm{Fe} . \mathrm{Zn}, \mathrm{Cu}$, and $\mathrm{Pb}$ ) were assessed by American Public Health Association standard methods (APHA, 2017). Drinking water quality analyzers were studied for temperature $\left(\mathrm{T}^{\circ} \mathrm{C}\right)$, electrical conductivity (EC), total dissolved solids (TDS), Hydrogen ion concentration $(\mathrm{pH})$.were determined in the field due to their unstable nature, and , Dissolved oxygen (DO), total hardness (TH), total alkalinity (TA) Chloride (Cl-), and Sulfate (SO4 2- ). The water samples were digested primarily in a mixture solution of $\mathrm{HNO} 3, \mathrm{HCl}(1: 3)$, then added $\mathrm{HClO} 4$ for further digestion. The total concentrations of $\mathrm{Zn}, \mathrm{fe}, \mathrm{Pb}$, and $\mathrm{Cu}$, in the digested samples were determined using flame atomic absorption spectrophotometry, the modle of AAS.

\section{RESULTS AND DISCUSSION}

TEMPERATURE $\left(\mathbf{T}^{\circ} \mathbf{C}\right)$ : Temperature is the main parameter for the study of well water. Temperature is a major factor of chemical and physical transformations in the water body and plays a main role in the metabolic activities of the organism. The value of well water temperature was found to be in the range from $\left(17.0\right.$ to $\left.23.4^{\circ} \mathrm{C}\right)$ during the study period. Maximum standard for temperature for drinking water is $25^{\circ} \mathrm{C}$.

Electrical conductivity (EC) in $\mu \mathrm{S} / \mathbf{c m}$ : Electrical conductivity is a major parameter in assessing water quality for agriculture purposes and is used for indicator of salinity. In this work, the concentrations of electrical conductivity in all sampling sites were ranged from (411 to $1579 \mu \mathrm{S} / \mathrm{cm}$ ). The higher well

The variation in the well water temperature may be due to the well depth and the influence of seasons. The higher well water temperature was observed in November at the Ashanke site, while the Lower water temperature was observed in March at site Dolla. These values were within the world standards. Similar results reported by (Snehalata et al ., 2018).

Total dissolved solids (TDS) in $\mathbf{m g} / \mathrm{L}$ : In the present investigation, the values of total dissolved solids are found in the range of (263 to 1010) $\mathrm{mg} / \mathrm{l}$ for the well water samples in the summer and winter seasons respectively (Figure 4 ). While the total mean value and standard error of mean values were $(348.63 \pm 3.625 \mathrm{mg} / \mathrm{L})$.

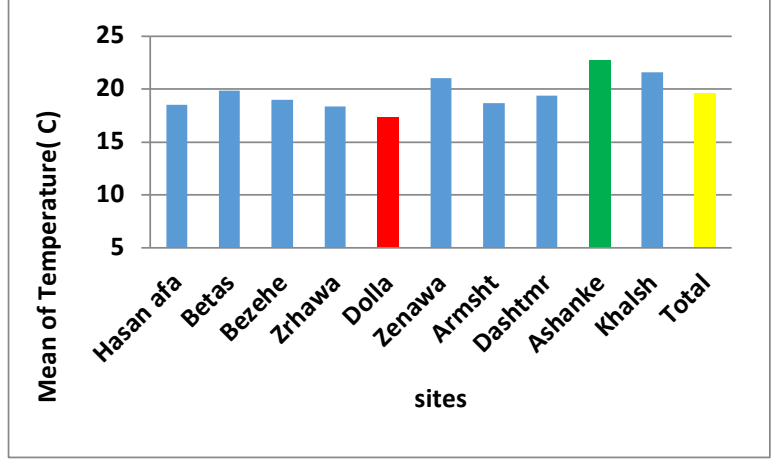

Figure (2) Mean of temperature $\left({ }^{\circ} \mathrm{C}\right)$ among selected well water conductivity were higher in Winter (Table 2). This might be due to the presence of inorganic dissolved solids such as sulfate, chloride, magnesium, sodium, calcium, and iron cations. The concentrations observed in all sampling sites were within the standard value of (WHO 2012) drinking water quality which is $1000 \mu \mathrm{S} / \mathrm{cm}$ except the locations Betas, Bezehe and Dolla. While the mean value and standard error of mean values was $(545.25 \pm 5.618 \mu \mathrm{S} / \mathrm{cm})$. These findings are lower than those reported by (Mustafa et al ., 2019).

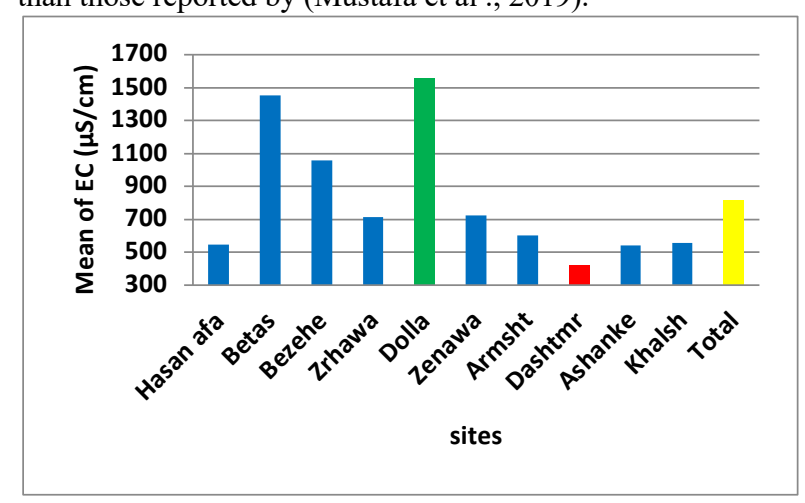

Figure (3) Mean concentration of Electrical conductivity

$(\mu \mathrm{S} / \mathrm{cm})$ among selected well water

The High value of total dissolved solids in this area may be due to the discharge from agriculture and untreated wastewater. According to (WHO., 2011), the maximum permissible limiting concentration of total dissolved solids for drinking water is $500 \mathrm{mg} / \mathrm{L}$. The TDS values were exceeded the permissible limit of $500 \mathrm{mg} / \mathrm{l}$ (WHO 2011) in three sites (Betas, Bezehe, Dolla) of the well water sampling sites in the winter and in the summer seasons. The higher concentration is due to the leaching of solid wastes from the ground surface as well as agriculture and animal waste. While the rest sites lied within the standard limits of drinking water. This paper are significantly higher than those reported by,( Neelam et al ., 2019).

Hydrogen Ion Concentration (pH): In the present study, the value of hydrogen ion $(\mathrm{pH})$ ranges between (7.1 to 8.3), for the well water samples during the summer and rainy seasons respectively (Figure-5) While the total mean value and standard error of mean values was $(7.4461 \pm 0.02750)$ and all the well water samples have value within the safe limit of 6.5 to 8.5 standard set by (WHO ., 2012). In the present study in most sites observed that $\mathrm{pH}$ is alkaline. The general increase of $\mathrm{pH}$ in well water is related to weathering of plagioclase feldspar in sediments. $\mathrm{pH}$ showed significant variations $(\mathrm{p}<$ 0.05). Similar results reported by,( Mustafa et al ., 2018).

Dissolved oxygen (DO) in $\mathbf{~ m g / L : ~ I n ~ t h i s ~ w o r k ~ t h e ~ v a l u e s ~ o f ~}$ dissolved oxygen are found in the range of 6.6 to- $8.7 \mathrm{mg} / \mathrm{l}$ for the well water samples in the summer and winter season respectively (Figure 6). While the total mean value and standard error of mean values were $(7.369 \pm .0724) \mathrm{mg} / \mathrm{L}$. The permissible limit of the DO in drinking water should be $\geq 5$ $\mathrm{mg} / \mathrm{L}$ (WHO, 2011). The DO values are above the permissible limit of $6.0 \mathrm{mg} / \mathrm{L}$ (WHO 2011) in most of the sampling in three sites (Betas, Bezehe, Dolla) of the well water sampling sites in the winter and in the summer seasons. The higher concentration is due to the leaching of solid wastes from the ground surface as well as agriculture and animal waste. While the rest sites lied within the standard limits of drinking water. This paper are significantly higher than those reported by, ( Neelam et al ., 2019). water conductivity were recorded in March at Dolla site, while the Lower water conductivity was observed in August at location Dashtmr. In Selevania District in all seasons electrical 


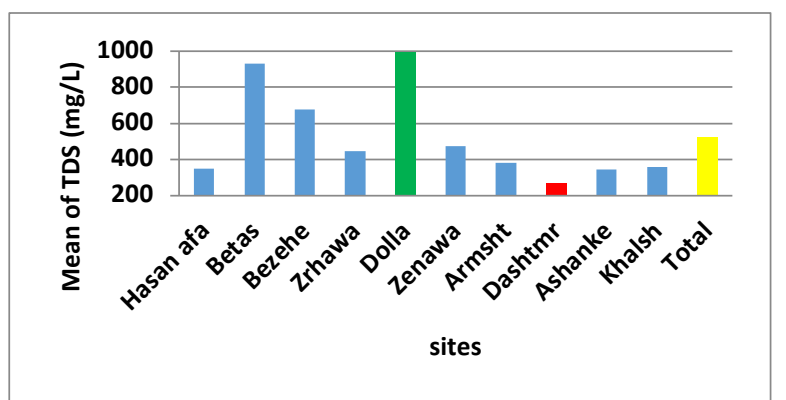

Figure 4: Mean concentration of TDS mg/L, among selected well water

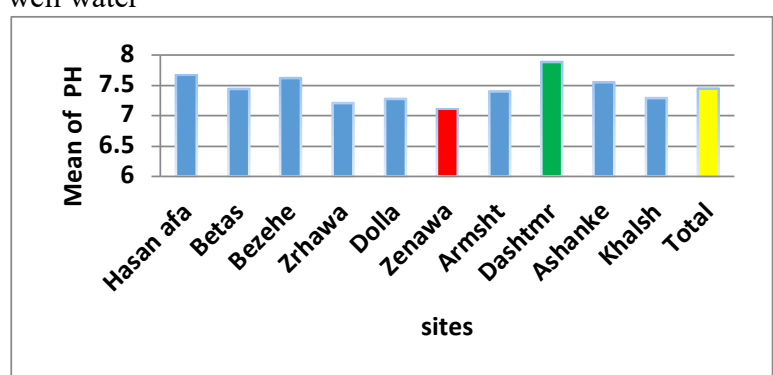

Figure (5) Mean concentration of $\mathrm{pH}$ value among selected well water

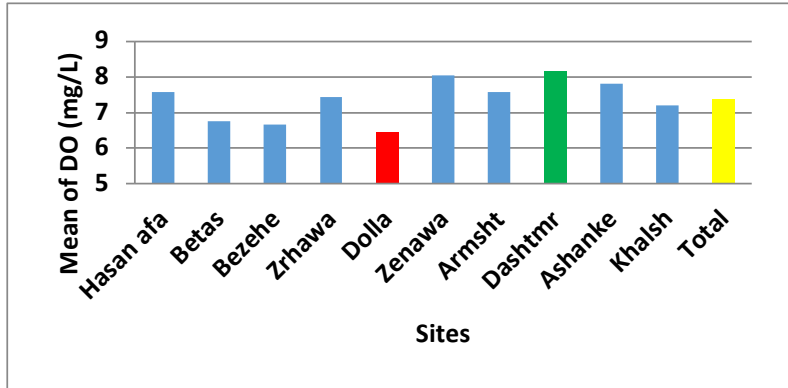

Figure 6: Mean concentration of dissolved oxygyn (DO)

$\mathrm{mg} / \mathrm{L}$, among selected well water

sites. Whereas the (DO) is found to be higher in all the well water samples .The oxygen content of natural waters varies with salinity, temperature, turbulence and atmospheric pressure. DO concentrations showed significant variations at $(p$ $<0.05$ ). This paper are lower than those reported by (Onuorah et al ., 2019).

Total hardness as $\mathrm{CaCO}_{3}$ in $\mathrm{mg} / \mathrm{L}$ : Hardness of water mainly depends on the amount of calcium and magnesium ions. The values of total hardness are found to be in the range of (176 to $848) \mathrm{mg} / \mathrm{L}$ for the well water samples in the summer and winter seasons respectively (Figure 7). While the total mean value and standard error of mean values were $(427.19 \pm 23.491)$ $\mathrm{mg} / \mathrm{L}$. The higher concentration of total hardness of $848 \mathrm{mg} / \mathrm{L}$ was observed in March, while the minimum value of $176 \mathrm{mg} / \mathrm{L}$ was found in August. When the well water is in contact with dolomite or limestone the hardness value tends to be very high, may be due to the addition of magnesium and calcium salts

Chloride (CL- ) in $\mathbf{~ m g / l : ~ . T h e ~ v a l u e ~ o f ~ C h l o r i d e s ~ i o n ~ o f ~ w e l l ~}$ water sample ranges from (11.6 to 56.9$) \mathrm{mg} / \mathrm{L}$, in the summer and winter seasons respectively. And the mean values were ranged $(12.550 \pm 0.3185)$ to $54.950 \pm 0.5127) \mathrm{mg} / \mathrm{L}$. (Figure $8)$. While the total mean value and standard error of mean values were $(28.651 \pm 1.6803) \mathrm{mg} / \mathrm{L}$ The chloride values of wells water samples were below the permissible limit of 250 $\mathrm{mg} / \mathrm{l}$ (WHO 2011). High concentration of chloride in well water may result from both natural and anthropogenic sources. In this paper are higher than those reported by (Durgasrilakshmi.,2019) was (6.7 to 33.1) $\mathrm{mg} / \mathrm{L}$.

Total alkalinity (TA) in $(\mathbf{m g} / \mathbf{L})$ : In the present study the total alkalinity value ranged between (287 to 584$) \mathrm{mg} / \mathrm{L}$, respectively in the summer and winter seasons. (Figure 9). While the total mean value and standard error of mean values were $(423.65 \pm 0.9 .019) \mathrm{mg} / \mathrm{L}$. The high total alkalinity is due to the When the well water is in contact with dolomite or limestone the hardness value tends to be very high , may be due to the addition of magnesium and calcium salts. The permissible limits of total hardness in drinking is $300 \mathrm{mg} / \mathrm{L}$ as given by (WHO 2012) standards for drinking water. The total hardness concentration exceed the permissible limit of 300 $\mathrm{mg} / \mathrm{L}$ at sampling sites. Betas. Bezehe, Zrhawa, Dolla, Zenawa and Armsht in summer and winter Season. According to these results. The permissible limits of total hardness in drinking is $300 \mathrm{mg} / \mathrm{L}$ as given by (WHO 2012) standards for drinking water. The total hardness concentration exceed the permissible limit of $300 \mathrm{mg} / \mathrm{L}$ at sampling sites. Betas. Bezehe, Zrhawa, Dolla, Zenawa and Armsht in summer and winter Season. According to these results, the well water in the study area was generally very hard. This paper are lower than those reported by ( Wajid et al ., 2019).

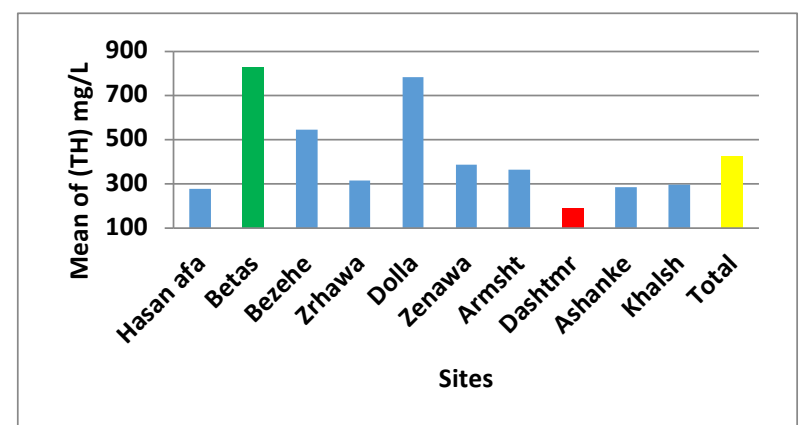

Figure 7: Mean concentration of total hardness among selected well water, $(\mathrm{mg} / \mathrm{L})$

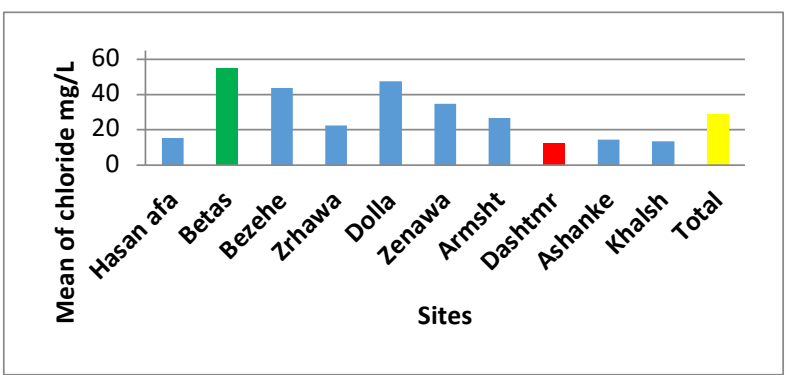

Figure 8: Mean concentration of Chloride among selected well water $\mathrm{mg} / \mathrm{L}$

presence of hydroxide, bicarbonates,and carbonates of potassium ,calcium, sodium, magnesium, sodium, and salts. According to (WHO., 2012) the desired limit and the maximum permissible limit for total alkalinity in potable water is 200 and $600 \mathrm{mg} / \mathrm{l}$, Seasonal variation influenced the values at different sites with alkalinity being higher in the winter season ( 584 $\mathrm{mg} / \mathrm{L}$ ). An increase in alkalinity during winters may be due to agricultral discharge, as well as high rainfall, Total alkalinity have been found to be high as compared to desired limit concentration, but alittle lower compared to the maximum permissible limit values of (WHO 2011) standards. In this paper are higher than those reported by (Aniqa et al 2019).

(Sulfate $\left(\mathrm{SO}_{4}{ }^{2-}\right)$ in $\mathrm{mg} / \mathrm{L}$ : Seasonal variations of sulfate at various sites are shown in (Figure 10). The lowest value (10.3 $\mathrm{mg} / \mathrm{L})$ was found in August and the highest value $(42.5 \mathrm{mg} / \mathrm{L})$ in winter showing the influence of seasons on values. Normally wellwater travels through rocks and soils a part of the sulfatecontaining minerals are dissolved. The sulfate values are well within the permissible limit of $250 \mathrm{mg} / \mathrm{L}$ (WHO 2011) While the total mean value and standard error of mean values was $(22.729 \pm 1.2312) \mathrm{mg} / \mathrm{L}$, in all sampling sites. The sulfate values are higher in the winter than the summer season. This 
paper are lower than those reported by (Hanumantharao et al ., 2019).

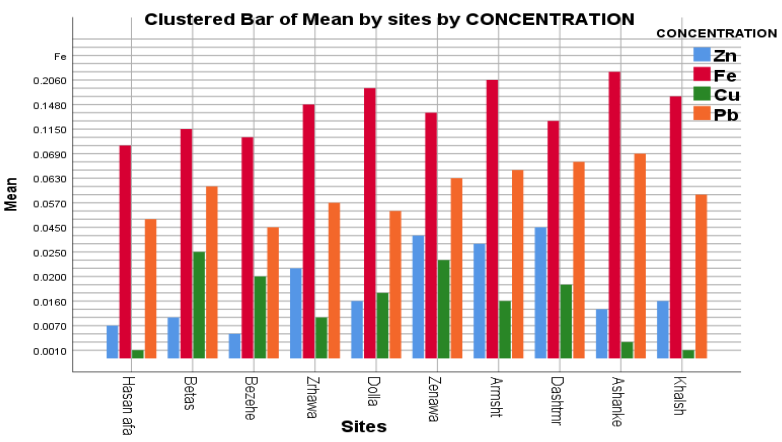

Figure (11) Mean concentration of $\mathrm{Pb}, \mathrm{Cu}, \mathrm{Zn}$, and $\mathrm{Fe}$ in well water samples $\mathrm{mg} / \mathrm{L}$.

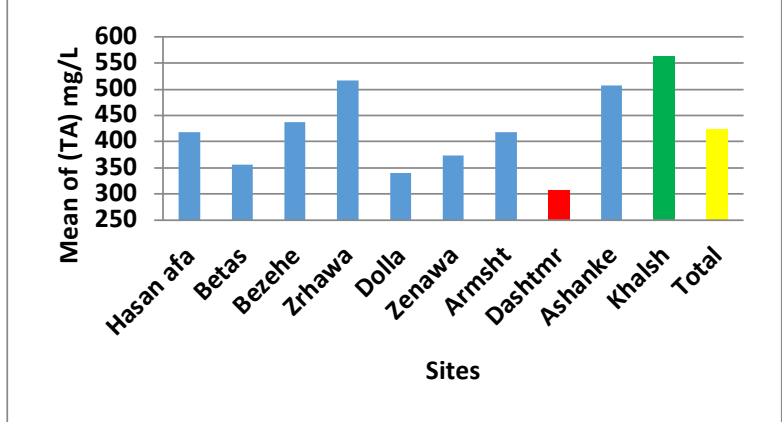

Figure (9) Mean concentration of total alkalinity among selected well water $\mathrm{mg} / \mathrm{L}$.

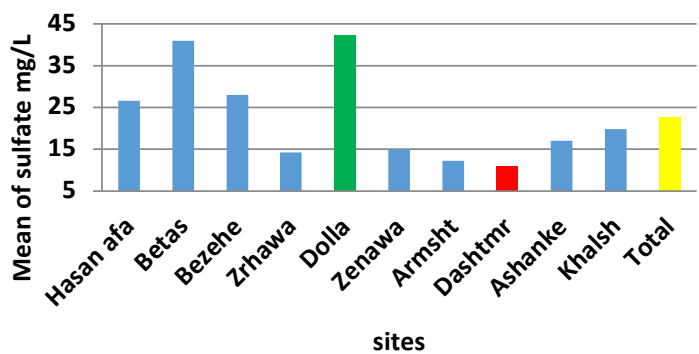

Figure (10) Mean concentration of sulfate $\mathbf{S O}_{4}{ }^{2-}$ a mong selected well water $\mathrm{mg} / \mathrm{L}$.
Mean concentration of $\mathrm{pb}, \mathrm{Cu}, \mathrm{Zn}$, and $\mathrm{Fe}$ in well water samples $\mathbf{m g} / \mathbf{L}$ : In this study, the mean concentrations of Zinc in well water samples ranged from $(0.027 \pm 0.004$ to $0.005 \pm$ $0.007) \mathrm{mg} / \mathrm{L}$, which within the permissible limit of $3.0 \mathrm{mg} / \mathrm{L}$ for drinking water. Set by (WHO., 2011). While the results obtained for the concentration of Fe ranged from $((0.0109 \pm$ 0.035 to $0.183 \pm 0.061) \mathrm{mg} / \mathrm{L}$. According to (WHO ., 2011), the permissible limit of $\mathrm{Fe}$ in drinking water is considered 0.3 $\mathrm{mg} / \mathrm{L}$. The mean concentration of $\mathrm{Cu}$ in well water samples ranged from $(0.001 \pm 0.022$ to $0.025 \pm 0.023) \mathrm{mg} / \mathrm{L}$. High concentration of $\mathrm{Fe}$ in well water occurs mainly through geological formation. These values were observed to be below the maximum permissible limits of $(2.0 \mathrm{mg} / \mathrm{L})$ according to (WHO.,2011). And the mean concentration of $\mathrm{Pb}$ in wells water samples ranged from $(0.045 \pm 0.015$ to $0.069 \pm 0.096)$ $\mathrm{mg} / \mathrm{L}$. High concentration of $\mathrm{Pb}$ in natural water occurs mainly through anthropogenic activities.

The permissible limit of $\mathrm{Pb}$ for drinking water is $0.05 \mathrm{mg} / \mathrm{L}$, (WHO ., 2008). The mean concentrations of the metals of all the drinking water samples were significantly lower than the permissible limits set by (WHO., 2011) standard for drinking water. The value of heavy metals are ranked as $\mathrm{Pb}>\mathrm{Zn}>\mathrm{Fe}>$ $\mathrm{Cu}$. In this paper are lower than those reported by (Nushe et al ., 2019).

\section{CONCLUSION}

The present work is conducted to evaluate chemical and physical properties of well water in the selevania region /Iraq. Most of the well water samples are permissible limits for drinking purpose recommended by the (WHO., 2012) . Results suggest that the well water quality in the study area is slightly alkaline and very hard in nature. It was found that TDS and total hardness in the sites Betas, Bezehe and Dolla were exceeding recommended limits in the water samples, which might prove to be harmful for health in the long term . The longterm of drinking water with higher concentrations of TDS and total hardness. It is suggested that such water should be used for drinking only after applying necessary treatments. Generally, most of the parameters in the waters samples were found to be within the limit of drinking water quality standards and are safe for dirking and other domestic purposes

Table 1: Physical-chemical properties of well water, data represented as mean \pm S.D, during studied period

\begin{tabular}{|c|c|c|c|c|c|c|c|c|c|c|c|}
\hline \multirow{3}{*}{$\begin{array}{l}\text { Sites } \\
\text { Hasan afa }\end{array}$} & & $\mathrm{T}^{\circ} \mathrm{C}$ & & $\mathrm{DS}$ & $\mathrm{pH}$ & DO & $\mathrm{TH}$ & $\mathrm{a}^{2+}$ & CL- & TA & $\mathrm{O}_{4}^{2-}$ \\
\hline & Mean \pm SE & 18.525 & $45.25 \pm$ & & $\pm 7.6763 \pm$ & $575 \pm 0$ & & & 15.450 & & \\
\hline & & & 5.618 & 3.625 & 0.017 & 1485 & 3.901 & 6.244 & 0.4040 & 6.425 & \\
\hline \multirow[t]{2}{*}{ Betas } & Mear & $19.838 \pm$ & 1454.25 & 593 & $\pm 7.4363 \pm$ & $6.750 \pm 0$ & $827.13 \pm$ & $640.88 \pm$ & $54.950 \pm$ & $356.63 \pm$ & $40.925 \pm$ \\
\hline & & 0.169 & \pm 5.596 & 3.5 & 0.019 & .0423 & 5.330 & 8.490 & 0.5127 & 4.330 & 8 \\
\hline \multirow[t]{2}{*}{ Bezehe } & & 19.0 & 1056.63 & & $\pm 7.6238 \pm$ & $6.662 \pm 0$ & 544 & $352.12 \pm$ & $43.825 \pm$ & $13 \pm$ & \\
\hline & & 0.19 & +5.38 & & 0.019 & .1413 & 3.1 & 5.3 & 84 & 4. & \\
\hline \multirow[t]{2}{*}{ Zrhawa } & $\mathrm{E}$ & $3 \pm$ & $715.38 \pm$ & & $\pm 7.2038 \pm$ & $7.438 \pm 0$ & & & & & \\
\hline & & 0.092 & 11915 & & b. 017 & 1068 & & 6.0 & & & \\
\hline \multirow[t]{2}{*}{ Dolla } & & $17.375 \pm$ & 1557.12 & & $\pm 7.2725 \pm$ & $6.438 \pm 0$ & & & $47.538 \pm$ & $13 \pm$ & $75 \pm$ \\
\hline & & 0. & \pm 5.0 & & 0.0 & .10 & 3. & 6. & 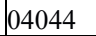 & & \\
\hline \multirow[t]{2}{*}{ Zenaw } & & 21.0 & $721.13 \pm$ & & \pm 7.1 & $8.038 \pm 0$ & 38 & & 34 & $5 \pm$ & \\
\hline & & 0. & 4.015 & & & 1101 & 1.8 & & 0.4511 & & \\
\hline \multirow[t]{2}{*}{ Armsht } & $\mathrm{E}$ & $18.662 \pm$ & $602.88 \pm$ & \pm 38 & $\pm 7.4050 \pm$ & $7.587 \pm 0$ & $13 \pm$ & 23 & $26.913 \pm$ & $75 \pm$ & $13 \pm$ \\
\hline & & & 4.533 & & & .07 & & & & & \\
\hline \multirow[t]{2}{*}{ Dashtmr } & SE & 194 & 42 & & & 8.17 & & & & & \\
\hline & & & 3.151 & & 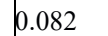 & 12 & & & 031 & & \\
\hline \multirow[t]{2}{*}{ Ashank } & $\mathrm{SE}$ & $22.750 \pm$ & $541.38 \pm$ & \pm 34 & $\pm 7.5575 \pm$ & $7.813 \pm 0$ & 28 & 19 & $14.388 \pm$ & $8 \pm$ & $0 \pm$ \\
\hline & & & & & & .139 & & & & & \\
\hline \multirow[t]{2}{*}{ Khalsh } & & & & & \pm 7.2 & & & & & & \\
\hline & & & & & & 14 & & & & & \\
\hline \multirow[t]{2}{*}{ Total } & SE & $19.654 \pm$ & 817.36 & $\pm 522.69 \pm$ & $\pm 7.4461 \pm$ & $7.369 \pm 0$ & $427.19 \pm$ & 250.74 & $28.651 \pm$ & 423.65 & $22.729 \pm$ \\
\hline & & 0.184 & 42.9 & 20 & 027 & 0724 & 23.49 & 16. & 1.6803 & 9.019 & 1.2312 \\
\hline & & & 1400 & & & & & 200 & 600 & 200 & 400 \\
\hline
\end{tabular}

Table 2: Physical-chemical properties of well water, data represented as mean \pm S.D, during studied period 


\begin{tabular}{|c|c|c|c|c|c|c|c|c|c|c|c|}
\hline \multicolumn{2}{|c|}{ Months } & $\mathrm{T}^{\circ} \mathrm{C}$ & $\mathrm{EC}$ & $\mathrm{TDS}$ & $\mathrm{pH}$ & $\mathrm{DO}$ & $\mathrm{TH}$ & $\mathrm{Ca}^{2+}$ & $\mathrm{Cl}$ & $\mathrm{TA}$ & $\mathrm{SO}_{4}{ }^{2-}$ \\
\hline Aug. & Mean \pm & $19.840 \pm$ & $814.20 \pm$ & $520.70 \pm$ & 7.3650 & $7.110 \pm$ & $414.60 \pm 6$ & 232.40 & 27.650 & 409.00 & $21.50 \pm$ \\
& $\mathrm{S.E}$ & 0.5327 & 123.944 & 79.31 & \pm 0.068 & 0.18 & 9.355 & \pm 47.62 & \pm 4.946 & \pm 25.84 & 3.5276 \\
\hline Sept. & Mean \pm & $20.020 \pm$ & $801.50 \pm$ & $511.70 \pm$ & 7.3840 & $7.130 \pm$ & $418.40 \pm 6$ & 232.10 & 27.720 & 411.90 & 21.510 \\
& $\mathrm{~S} . \mathrm{E}$ & 0.5274 & 7.849 & 82.03 & \pm 0.068 & 0.18 & 9.418 & \pm 45.63 & \pm 4.947 & \pm 26.42 & \pm 3.542 \\
\hline Oct. & Mean \pm & $19.950 \pm$ & $808.00 \pm$ & $519.30 \pm$ & 7.4000 & $7.120 \pm$ & 420.90 & 240.50 & 27.880 & 413.50 & 21.540 \\
& S.E & 0.5408 & 27.038 & 81.90 & \pm 0.070 & 0.17 & \pm 69.453 & \pm 49.92 & \pm 4.894 & \pm 25.50 & \pm 3.540 \\
\hline Nov. & Mean \pm & $20.130 \pm$ & $809.10 \pm$ & $517.40 \pm$ & 7.4030 & $7.210 \pm$ & $418.80 \pm 6$ & 244.60 & 28.100 & 418.00 & 22.560 \\
& S.E & 0.5496 & 126.987 & 81.35 & \pm 0.068 & 0.18 & 9.777 & \pm 48.52 & \pm 4.998 & \pm 26.00 & \pm 3.681 \\
\hline Dec & Mean \pm & $19.780 \pm$ & $814.50 \pm$ & $520.60 \pm$ & 7.4260 & $7.250 \pm$ & $435.50 \pm 6$ & 249.30 & 28.340 & 422.50 & 22.970 \\
& S.E & 0.5206 & 127.428 & 81.54 & \pm 0.070 & 0.18 & 8.274 & \pm 48.65 & \pm 4.979 & \pm 26.57 & \\
\hline Jan. & Mean \pm & $19.320 \pm$ & $823.80 \pm$ & $527.30 \pm$ & 7.4760 & $7.510 \pm$ & $431.20 \pm 7$ & 259.60 & 29.240 & 431.70 & 23.600 \\
& S.E & 0.5316 & 127.899 & 81.82 & \pm 0.074 & 0.20 & 0.173 & \pm 48.27 & \pm 4.925 & \pm 26.77 & \pm 3.696 \\
\hline Feb. & Mean \pm & $18.830 \pm$ & $830.80 \pm$ & $530.40 \pm$ & 7.5420 & $7.740 \pm$ & $436.30 \pm 6$ & 268.30 & 29.880 & 438.00 & 23.910 \\
& S.E & 0.4879 & 128.089 & 82.11 & \pm 0.092 & 0.20 & 9.656 & \pm 48.41 & \pm 4.973 & \pm 27.03 & \pm 3.676 \\
\hline Mar. & Mean \pm & $19.360 \pm$ & $837.00 \pm$ & $534.10 \pm$ & 7.5730 & $7.880 \pm$ & $441.80 \pm 7$ & 279.10 & 30.400 & 444.60 & 24.290 \\
& S.E & 0.5319 & 127.706 & 81.88 & \pm 0.102 & 0.20 & 0.080 & \pm 48.11 & \pm 5.070 & \pm 27.05 & \pm 3.684 \\
\hline Total & Mean \pm & $19.654 \pm$ & $817.36 \pm$ & $522.69 \pm$ & 7.4461 & $7.369 \pm$ & $427.19 \pm 2$ & 250.74 & 28.651 & 423.65 & 22.729 \\
& S.E & 0.1843 & 42.927 & 27.52 & \pm 0.027 & 0.07 & 3.491 & \pm 16.35 & \pm 1.680 & \pm 9.019 & \pm 1.231 \\
\hline
\end{tabular}

Table 3: WQI values for Khabur River during studied period

\begin{tabular}{|c|c|c|c|c|c|c|c|c|c|c|}
\hline $\begin{array}{c}\text { Canadian } \\
\text { WQI }\end{array}$ & Hasanafa & Betas & Bezehe & Zrhawa. & Dolla & Zenawa & Armsht & Dashtmr & Ashanke & Khalsh \\
\hline Drinking & Good & Poor & Poor & Good & Poor & Good & Good & Very good & Very good & Very good \\
\hline Irrigation & Excellent & Good & Good & Very good & Good & Excellent & Very good & Excellent & Excellent & Excellent \\
\hline
\end{tabular}

\section{REFERENCES}

(APHA) American Public Health Association (APHA) (2017) Standard methods for examination of water and wastewater, 23rd edn APHA, AWWA, WPCF, Washington

Adam Khalifa Mohamed1,2,*, Liu Dan1, Song Kai1, Elsiddig Eldaw1,2, and Salma Abualela2 2019Evaluating the suitability of groundwater for drinking purposes in the North Chengdu Plain, ChinaE3S Web of Conferences 81, $01006(2019$

Aniqa Batool,1 Nafeesa Samad,1 Syeda Sabahat Kazmi,2 Muhammad Asad Ghufran,3 Saima Imad,2 Mateen

Shafqat,1 Tariq Mahmood 2019 Spring water quality and human health: an assessment of natural springs of margalla hills Islamabad zone- Volume 2 Issue 1 - 2018

Baskoro Rochaddi* , Warsito Atmodjo1, Alfi Satriadi1 , Chrisna Adhi Suryono2, Irwani Irwani2 and Sugeng

Widada 2019 The Heavy Metal Contamination in Shallow Groundwater at Coastal Areas of Surabaya East Java Indonesia Jurnal Kelautan Tropis Maret 2019 Vol. 22(1):69-72

Durgasrilakshmi Hari 2019 Groundwater Quality Assessment in Kattedan Industrial Area, Hyderabad India International Journal of Recent Technology and Engineering (IJRTE) ISSN: 2277-3878, Volume-8 Issue-1, May 2019

Hanumantharao.C, Koteswararao.M, Kalyan.T 2019 Groundwater Quality Assessment for Drinking Purpose in Vijayawada Region, Andhra Pradesh, India International Journal of Engineering and Advanced Technology (IJEAT) ISSN: 2249-8958, Volume-8 Issue-5, June 2019

Jabal MSA, Abustan I, Rozaimy MR, El Najar H (2015) Groundwater beneath the urban area of Khan Younis City, southern Gaza Strip (Palestine): hydrochemistry and water quality. Arab J Geosci 8:2203-2215

Mohamed Hanipha M* and Zahir Hussain A 2017 Seasonal Variations of Groundwater Quality in and around Dindigul Town, Tamilnadu, India Pelagia Research Library.Der Chemica Sinica, 2017, 8(2):235-241

Mustafa I Umer1, Payman A Abduljabar2 and Newar

A M Hamid2 2018 Assessment of Ground Water Pollution by Heavy Metals and Anions in Kwashe Industrial Area, Duhok City, Kurdistan Region. Iraq IOP Conf. Series: Materials Science and Engineering 454 (2018).

Neelam Bunkar1* and Vinod Kumar 2019 Water Quality Index for Assessment of Groundwater Quality Parameters in Udham
Singh Nagar District of Uttrakhand Int.J.Curr.Microbiol.App.Sci (2019) Special Issue-8: 68-72

Nushe Lajçi1,*, Milaim Sadiku1, Xhemë Lajçi2, Blerim Baruti1, Mehush Aliu1 2017 Assessment of Physico-Chemical Quality of Fresh Water Springs in Village Pepaj, Rugova Region, Kosova J. Int. Environmental Application \& Science, Vol. 12(1): 73-81 (2017)

Onuorah Samuel*, Igwemadu Nkiruka, Odibo Frederick 2019 Effect of Seasonal Variation on the Physicochemical Characteristics of Borehole Water in Ogbaru Communities, Anambra State, Nigeria Natural Resources and Conservation 7(1): 1-8, 2019

Punia A. 1,*, Siddaiah N.S.2 , Bharti R.1 2019 Groundwater Quality and Hydrogeochemical Characterization of Khetri Copper Mining Region, India 16 th International Conference on Environmental Science and Technology Rhodes, Greece, 4 to 7 September 2019

Snehalata Kotagi 1, J K Sandhya Kiran 2018 Physico-Chemical Analysis of Ground Water International Journal of Innovative Research in Science, Engineering and Technology Vol. 7, Issue 1, January 2018

Tajinder Kaur1 • Renu Bhardwaj1 • Saroj Arora 2016 Assessment of groundwater quality for drinking and irrigation purposes using hydrochemical studies in Malwa region, southwestern part of Punjab, India Appl Water Sci DOI 10.1007/s13201016-0476-2

Wajid Ali , Muhammad Nafees, Syed Ali Turab , M. Younis Khan , Khaista Rehman 2019 Drinking water quality assessment using water quality index and geostatistical techniques, Mardan District, Khyber Pakhtunkhwa, Pakistan Journal of Himalayan Earth Sciences Volume 52, No. 1, 2019 pp. 6585

WHO (2012)., Guidelines for Drinking-water Quality., Second edition, Addendum to 2, Health Criteria and Other Supporting Information

WHO (2011)., Guidelines for Drinking-water Quality., Second edition, Addendum to 2, Health Criteria and Other Supporting Information

Yousra Souidi (1,2), Hanen Jarray (1), Hafedh Rigane (2), Raul Carrey Labarta (3), Manuela Barbieri (3), Albert Soler Gil (3), Faiza khalfalli (4), and Mohamed

Moussa (1 2019 Evaluation of groundwater quality and its suitability for drinking and irrigation purposes: Case of Skhira aquifer Sfax -TunisiaGeophysical Research Abstracts Vol. 21, EGU2019-1893-2, 2019 